\title{
The Role and Implication of an Infantry Unit on the Issues of Disaster Management
}

\author{
${ }^{1}$ Ridzuan, A.A., ${ }^{1}$ Mohd Zainol, N.A., ${ }^{1}$ Ismail, Z., ${ }^{1}$ Yaacob, S., ${ }^{1}$ Abdullah, H. and ${ }^{1}$ Ungku Zahar, U.A. \\ ${ }^{1}$ Faculty of Defence Studies \& Management, National Defence University of Malaysia, Sungai Besi Camp, 57000 Kuala Lumpur.
}

Correspondence Author: Ridzuan, A.A., Faculty of Defence Studies \& Management, National Defence University of Malaysia, Sungai Besi Camp, 57000 Kuala Lumpur.

Tel: +60192726202; E-mail: azan6142@yahoo.com

Received date: 12 January 2018, Accepted date: 10 March 2018, Online date: 20 March 2018

Copyright: (C) 2018 Ridzuan, A.A. et al. This is an open-access article distributed under the terms of the Creative Commons Attribution License, which permits unrestricted use, distribution, and reproduction in any medium, provided the original author and source are credited.

\begin{abstract}
The infantry unit involvement in operation other than war such as deployment at all types of disaster environment had shown the efficient disaster response. They are self contains supported by the comprehensive structure, sufficient equipment, trained personnel, highly mobile and reliable assistance when the time required The purpose of this paper: firstly, to introduce the role of infantry unit throughout a range of crisis situations, ranging from emergencies, to disasters, to catastrophes, primarily from a Malaysian perspective. Secondly, this paper will examine the implications of infantry unit deployment for the disaster management. Interviewed and focus group discussion was conducted with several personnel from infantry unit in Peninsular Malaysia, Sabah, and Sarawak that have experienced deployed to response during the disaster especially natural disaster-flood There was a controversy exists such as how to best place the infantry unit within the management cycle and to what extent the model for infantry unit is appropriate. This paper will also discuss on the issues of command and control decision making structures, and the usage of infantry unit assets in disaster management. The infantry unit support of civilian authorities has become a well-known phenomenon, nationally as well as internationally. The infantry unit response is reserved primarily for larger scale disaster operations. The paper includes further discussions, implications and conclusion.
\end{abstract}

Key words: Infantry unit; Disaster management; Command and control; Infantry unit assets

\section{INTRODUCTION}

In recent years national and international militaries have played an increasingly important role in crisis relief efforts, and disaster management in particular has come to be seen as one of their core tasks [1]. The typical fundamental combat mission of the Malaysian Armed Forces (MAF), regardless of their services, is to close with the enemy by means of fire and maneuver to destroy or capture him or to repel his assaults by fire, close combat, and counterattack [2]. For combat mission is not only their primary task because during peacetime, the MAF are also required to respond to disaster to assist the Civil Authorities in times of emergency when duty calls and operate under the leading federal agency and comply with provisions of National Security Council (NSC) Directive No. 20 (The Policy and Mechanism on National Disaster and Relief Management).

According to National Security Council (NSC) [3], the role and duty of MAF in handling disaster on scene are: 1) to support by offering services of members from all ranks during disaster; 2) to support in providing limited transportation vehicle for land, air or sea at all level of disaster; 3 ) to assist with preparing machinery equipment facilities to be used in relation to disaster at all level; 4) to provide skill services, such as experts in explosive, engineering, communication and any form of aid if necessary; 5) to assist with construction works if needed to facilitate the operation during a disaster; 6) to provide divers services; to carry out search and rescue operation base on necessity during a disaster; 7) to prepare 'Air Ambulance' as first aid and to evacuate victims; 8) to provide 'liaison officers' at all level; 9) and to offer emergency relief services when MAF is the first agency to reach the place of incident and will only hand over the responsibility when official authority on disaster arrived to continue works according to the issued directive. MAF by nature of its structure, organization, training, readiness and inventory capabilities is seen as an appropriate organization to respond to humanitarian and disaster relief operations.

The purpose of this paper will specifically examine two main issues: firstly, to introduce the role of infantry unit throughout a range of crisis situations, ranging from emergencies, to disasters, to catastrophes, primarily from a Malaysian perspective. Secondly, this paper will examine the implications of infantry unit deployment for the disaster management. This paper will also discuss on the issues of command and control decision making structures and the usage of infantry unit assets in disaster management.

\section{Methodology:}

Interviewed and focus group discussion was conducted with several personnel from infantry unit in Peninsular Malaysia, Sabah, and Sarawak that have experienced deployed to response during the disaster especially natural disaster-flood. The interview questionnaires were developed in such a way as to learn, inter alia, about respondents' past experiences involved in disaster management, involving the role of infantry in disaster management cycle, and what they know about implications of infantry unit on the issues of disaster management. The semi structured interview was conducted involving several experienced infantry unit officers comprising the commanding officer, senior officer operation, senior officer training, administrative officer, and logistic staff officer who had the relevant experience in response during the disaster. Interview questions and responses are typically tape-recorded and then transcribed verbatim before analysis is begun. 
Citation: Ridzuan, A.A., Mohd Zainol, N.A., Ismail, Z., Yaacob, S., Abdullah, H. and Ungku Zahar, U.A.,, 2018. The Role and Implication of an Infantry Unit on the Issues of Disaster Management. Advances in Natural and Applied Sciences., 12(3): 51-54.

The data is categorized into patterns as the primary basis for organizing and reporting results. Information gathered from the in-depth interview will be used as a primary basis for organizing, interpreting and reporting results.

\section{The Role of Infantry Unit within the Disaster Management Cycle:}

The term disaster by the United Nations [4] is defined as a serious disruption of the functioning of society, causing widespread human, material, or environmental losses which exceed the ability of affected society to cope using only its own resources. According to the Malaysian National Security Council (NSC, Directive No. 20), disaster is, a sudden, catastrophic event, resulting in the loss of lives on a large scale, destruction of properties and environment, leading to severe disruption in activities of the community which requires intensive management of multiple resources, involving multi agencies networking which include equipment, shelter, logistic support, infra-structure and human resources. The damage caused by disaster depends on climate, the geographical location and the type of the earth surface/degree of vulnerability and the mental, socio-economic, political and cultural state of the affected area in general [5-7].

According to Coppola [8], Ahmad Azan [9], and UNISDR Terminology on Disaster Risk Reduction. [10], disaster management cycle, typically is understood to encompass the four interdependent phases of mitigation, preparedness, response and recovery. Mitigation refers to long-term actions that reduce the risk of natural disasters, such as constructing dams and prohibiting people from building homes or businesses in high-risk areas. Preparedness involves planning for disasters and putting in place the resources needed to cope with them when they happen. Examples include stockpiling essential goods and preparing emergency plans to follow in the event of a disaster. Response refers to actions taken after a disaster has occurred. The activities of police, firefighters, and medical personnel during and immediately after a disaster fall into this category. Recovery encompasses longer-term activities to rebuild and restore the community to its pre-disaster state. These four phases may overlap and the end of the one phase and the beginning of the next isn't always clear. Response and recovery may be occurring simultaneously, and different agencies may end response and begin recovery at different times. Mitigation is part of preparedness but begins during response and continues during the recovery phase. These four categories may be a useful way for conflict resolution professionals to understand what happens during a disaster and to design interventions appropriately.

Infantry is essentially an arm of close combat. Its role is to seek out and locate the enemy, to kill or capture him, to seize and hold ground and repel attack, by day or night regardless of season, weather or terrain. Fit, well-armed men are the backbone of the infantry battalion. It is by determinations and by skilful use of weapons and ground conditions that the battalion will succeed in battle. For instance, within the scope of Kelantan Floods the military sent an 8 Brigade Group of over 1000 army, personnel to provide assistance in response to the 26 December 2014 floods. These personnel, just like other personnel belonging to Armed Forces of different countries as well as civilian specialists, provided search and rescue, the provision of large amounts of emergency medical supplies, food, water, tents, tarpaulins, reverse osmosis water purification units, and field hospitals to provide medical care to remote areas of the country. Moreover, military police assisted civilian police to safeguard civilian aid workers while distributing food and water. Military engineers removed debris; they reopened roads and other transportation links and, in this way,, they enable military transportation units to provide aid to the stricken communities [11-12]. The military's response is reserved primarily for larger scale disaster operations. The mainstream view is that the military plays a limited and supplementary role. According to UNOCHA statistics, humanitarian assistance can be broken down into approximately $40 \%$ food, $10 \%$ health and sanitation, and other key sectors including water, agriculture, and economic infrastructure. Only $0.1 \%$ of the total humanitarian assistance is directly related to security [13]

\section{The Implications of Infantry Unit Deployment for the Disaster Management:}

Natural disasters such as floods, hurricanes, and drought not only cause massive loss of life and property but also destroy everything necessary for human sustenance. Chaos theory provides a method for describing and explaining the behavior of nonlinear systems. It tends to be different from traditional scientific theory in that it focuses on interrelationships rather than individual elements [14]. The implications of infantry unit deployment for the disaster management especially during the course of planning, conducting and delivering assistance for the disaster management, the infantry unit had exposed many lessons such as:

a. Rapid response is the most important factor in the initial phase of disaster management operations to minimize the loss of lives. Disasters like floods, earthquakes, and tsunamis defy predictions and generally rescue teams were caught unprepared to deal with the massive response missions required. To address this problem, there is a need for disaster preparedness amongst infantry unit and civilian agencies in respective states or districts.

b. Communication must be established immediately at the disaster areas to pass timely and accurate information back to assisting affected states or districts. Situation in disaster-stricken areas are normally very chaotic and it is often difficult to get an accurate assessment of the situation which is vital for disaster response and recovery. This timely information will facilitate the distribution of manpower and resources accordingly.

c. Disaster response and recovery must be carefully plan and relevant to meet the victims needs which changes over time. Disaster response and recovery, therefore should be conducted by phases i.e., search and rescue phase, stabilization phase, reconstruction and rehabilitation phase. Rescue activities, provision of medical aids, food and shelter would be the primary needs in the initial phase. Subsequently during stabilization, reconstruction and rehabilitation phases, the continuation of medical attention, relocation of victims, clearance of debris and providing other logistics support at the stricken areas would be the main focus. Therefore, the needs in the various phases should be correctly identified so that appropriate aids and assistance could be delivered.

d. Coordination of infantry unit with lead agency is another important factor in ensuring success in disaster response and recovery operations. Assistance delivered unilaterally becomes duplications, waste and possibly a liability. Coordination of response and recovery efforts is absolutely necessary to maximize benefits, reduce duplications and ensure effective organization through pooling of resources. Coordination is also required to address the political, social, and legal issues with the states or districts which can hinder smooth conduct of response and recovery operations.

e. Disaster response and recovery operation should compose of multi-functional skills teams in planning, organizing, directing and control especially for post-disaster reconstructions. Initial search and rescue team should have composed of rescue experts, medical doctors and assistants, cooks, drivers and general workers for administrative works to sustain the rescue efforts. Participants of infantry unit and others expert units in disaster response and recovery operation must be well trained in their respective fields.

\section{The Issues of Command and Control:}

A primary need in the disaster area is effective command and control in the early stages of an emergency [15]. The military has many combinations of highly mobile and globally capable command and control elements, both within the active component and ready in each state within the infantry unit. Chaos theory is an important issue in disaster management because a kind of chaotic condition is experienced especially within the first 72 hours of a disaster [16-17]. In the event of a natural disaster, the infantry unit would be given responsibility for providing essential command and control capability to local authorities immediately for the first 48 to 72 hours [15]. This would enable other leaders and agencies at all levels to come into play without vacuum of capability. As district, state and federal authorities ramp up to full capability, these command and control capabilities and functions would be passed to other authorities as they come on line. This concept cannot be made a reality unless extensive planning and coordination provide a framework for implementation. To adequately prepare for a disaster would involve anticipating multiple requirements; meeting those requirements in detail would involve coordinated contingency plans by numerous agencies. The scenario for each type of emergency would be unique to the potential threat and require specialized responses.

According to Newman, et. al. [14], chaos theory becomes highly important in disaster management as it proposes a flexible organizational structure which grounds on alteration and enables continuous flow of information instead of a linear approach; an organizational structure which is simply based on command and control. The Malaysian cabinets view requirements for military support in civilian domestic affairs as situation-specific. When appropriate governmental authority directs the military to assist in domestic emergencies within the peninsular, Sabah and Sarawak, the infantry unit has a primary responsibility to provide support [18].

\section{The Usage of Infantry Unit Assets in Disaster Management:}

Focusing on military capabilities in natural disaster, the military assets which were worldwide provided during the period 1997-2006 were: communications, engineering, medical support, power supply and distribution, search and rescue, transport, logistics and coordination, sea and inland water, and water and sanitation. Among those assets, air transport, logistics and coordination, medical support and expert personnel were mostly deployed [19]. The Armed Forces have deployed 5,000 active military personnel, 89 militaries 3 ton trucks, 62 assault boats, 57 outboard machine, 27 Landrover, 19 TATRA trucks, 13 field kitchens, 30 
GIRN communication sets, 2 Agusta helicopters, 4 EC725 Cougar helicopters, 2 NURI helicopters, 2 C130 aircrafts, 1 Fennec helicopters, 1 Super Lynx helicopters, and 1 divers team in 2014/2015 Kelantan flood areas [20-21].

The current NSC response system is built on tiered response, a methodical employment of emergency responder assets very appropriate for dealing with disaster on a normal scale. In tiered response, district leaders turn to state resources when they are exhausted. In turn, states to federal when their means are exceeded. Both must communicate their requirement to federal officials and manage the response effectively.

In most disasters cases, district resources handle things in the first hours and days until federal resources can be requested, marshaled, and rushed to the effected disaster scene. Deploying federal resources usually takes days, and usually that's all right, because district and state responders are capable of both providing aid and instilling confidence until reinforcements arrive. When district and state assets are overwhelmed during a disaster, it is appropriate for military assets to be brought in to bridge the gap until civilian agencies responders can handle the situation. Last resort does not necessarily mean last. We can and will use military assets first if it is considered the best way to save lives [and/or] alleviate suffering. Wiharta et al. [22] stated that a military commander has the authority to act independently to render immediate aid within the first 72 hours.

Infantry assets have been an integral part of the community's humanitarian responses to many major, rapid-onset natural disaster, and they are likely to remain so far the foreseeable future. There are aspects that influence the effectiveness and desirability of deploying infantry assets in response to a natural disaster as follows:

a. Timeliness: seems to be the main factor affecting the effectiveness of infantry unit assets in a natural disaster response, especially in the first days and weeks of the operation.

b. Appropriateness and competence: needs assessments are very important.

c. Efficiency: depends not only on the efficiency with which it carries out its assigned tasks but also on how well its capabilities are used within the larger operation.

d. Absorptive capacity: which individual infantry assets tend to be relatively self-sufficient and thus to place a small burden on absorptive capacity, the arrival of large numbers of other agencies assets and with overlapping capabilities can cause serious problems.

e. Coordination: between civilian humanitarian actors and infantry unit assets has been one of the greatest challenges created by the increase deployment of other agencies assets. Differences in cultures, priorities and operating modes have an impact not least on information sharing. The role is best and most suitably carried out by the lead agency.

f. Costs: of deploying infantry unit assets are generally higher than for civilian assets. This has caused concerns that infantry assets are placing a disproportionate burden on disaster fund. However, defense ministry covers some or all of the costs deploying infantry unit assets for disaster relief.

\section{Recommendations and Conclusion:}

From a military perspective, providing assistance to civil authorities is perceived as a secondary task of the infantry unit today, as being part of a more open and democratic society means greater participation in civilian and overall nation-building activities. The infantry unit contribution to HADR missions lies in its ability to estimate the consequences of disasters and the major risk factors for human casualties. Four distinct models can be identified in which infantry unit are deployed in a humanitarian role and which can affect overall success and performance:

Detached deployment of infantry unit assets: this is the most common model - the infantry unit establishment simply donates commodities or lends equipment and the necessary personnel to operate them. Civilian control over deployment is inherent in this model and the most successful applications of military assets usually follow.

Use of infantry units to augment civil manpower: in this model infantry units are used to provide additional manpower usually and occurs during or immediately after a disaster. Popular roles are flood and fire-fighting, debris clearance, post-disaster security and control.

Use of the infantry units in security and police roles: this is perhaps the most common role for national infantry units in civil emergencies is an extension of local police forces. With proper training and subordination to civil authority, this is an effective role for the infantry unit.

The main challenge will be for infantry unit to plan effective cooperation with civilian authorities for an efficient response. As been witnessed during the last decade, there is a trend for armed forces around the world to go beyond traditional war-fighting and take on civil humanitarian tasks. The military support of civilian authorities has become a well-known phenomenon, nationally as well as internationally.

\section{REFERENCES}

[1] Humanitarian Policy Group HPG., 2012. Roundtable on Civil-Military Coordination summary note. Responding to natural disasters: Coordination between national armies, regional organizations, and humanitarian actors in the Asia Pacific Region. Bangkok, Thailand.

[2] MP 1.3.8A TD. 2005. ARTEP Batalion Infantri Standard (BIS) (Sementara).

[3] National Security Council (NSC). 2012. National Security Division, Prime Minister Department. Directive No. 20. Policy and Mechanism of National Disaster Management and Relief.

[4] UNDP/UNDRO, 1992. An Overview of Disaster Management, $2^{\text {nd }}$ ed. Disaster Management Training Programme. United Nations.

[5] Rahman, A.B., 2012. Issues of Disaster Management Preparedness: A Case Study of Directive 20 of National Security Council Malaysia. International Journal of Business and Social Science., 3(5): 85-92.

[6] Press, F., \& Hamilton, R. M. (1999). Mitigating Natural Disasters. Science., 284: 5422, p: 1927.

[7] Ergünay, O., 1996. "Afet yönetimi nedir? Nasıl olmalıdır? Erzincan ve Dinar Deneyimlerinin Işı̆̆ında Türkiye’nin Deprem Sorunlarına Çözüm Arayışları", TÜBITAK Earthquake Symposium Proceedings Book, Ankara.

[8] Coppola, D., 2006. Introduction to International Disaster Management, Butterworth-Heinemann.

[9] Ahmad Azan, R., U.Z. Ungku Azly and H.K. Mohd Juraimy, 2011. Disaster Basics: The Life Cycle of the Disaster Management and Roles of Agencies in Malaysia. Journal of Occupational Safety and Health NIOSH Malaysia, June, 8.

[10] UNISDR Terminology on Disaster Risk Reduction, 2009. International Strategy for Disaster Reduction. Retrieved from http://www.unisdr.org/eng/terminology/terminology-2009-eng.html

[11] National Defense and the Canadian Forces, 2010. National Defence and Canadian Forces (DND/CF) | Défense Nationale et les Forces Canadiennes (MDN/FC). Retrieved from http://www.forces.gc.ca /site/home-accueileng.asp.

[12] Etkin, D., K. McBey and C. Trollope, 2011. The Military and Disaster Management: A Canadian Perspective on the Issue. Retreived from http://www.crhnet.ca/resources/onlineBook/ Etkin.pdf.

[13] UNOCHA, 2009. Annual Report 2009: Participants: Governmental Disaster Management Agencies, cited in Chapter 8, Damon P. Coppola, Introduction to International Disaster Management, second edition (Amsterdam: Butterworth-Heinemann), p: 455.

[14] Newman, I., C. Wessinger and R. Bobner, 1993. Chaos Modeling: An Introduction and Research Application. Midwestern Educational Researcher, 6(2): 2-6.

[15] Bradford, Jr., Z.B. and F.J. Brown, 2006. America's Army as First Responder. Landpower Essay. An Institute of Land Warfare Publication. No.06-1, April.

[16] Pine, J., 2006. "The Contributions of Management Theory and Practice to Emergency Management", In McEntire, David (ed.) Disciplines, Disasters, and Emergency Management. Federal Emergency Management Agency: Emmitsburg, MD.

[17] Koehler, G.A., 1996. "What Disaster Response Management Can Learn from Chaos Theory", Conference Proceedings May 18-19 (1995), California Research Bureau, California

[18] MD 3.0 TD. 2005. Operations Other Than War. Chapter 8.

[19] Homan, K., 2008. Military Support to Civilian Authorities. Key-note speech delivered at NATO's 2008 Civil protection Committee Seminar: Civil-Military Cooperation and Interaction, Sibenik, Crotia, pp: 1-6. 
[20] PostMetro, 2014. Meninjau Kesiapsiagaan ATM dan Membantu Mangsa Banjir melalui Ops Murni. Nasional, 29 Disember. Muat turun dari http://postmetro.net/meninjau-kesiapsiagaan-atm-dan-membantu-mangsa-banjir-melalui-ops-murni/.

[21] Muhamad Hafiz, Y.B., 2015. ATM Komited Bantu Mangsa Banjir. Utusan Online 7 Januari. Muat turun dari http://www.utusan.com.my/berita/nahasbencana/atm-komited-8232-bantu-mangsa-banjir-1.45465\#sthash.xaYuR0GM.dpuf.

[22] Wiharta, S., H. Ahmad, J.Y. Haine, J. Löfgren and T. Randall, 2008. The Effectiveness of Foreign Military Assets in Natural Disaster Response. Stockholm International Peace Research Institute (SIPRI). 